\title{
STUDIES ON THE OLFACTORY FATIGUE
}

Part I: Methods of the examination of the olfactory fatigue

Part II: Observations of the olfactory fatigue by the increasing stimulus method.

Part III: On the relation concerning olfactory fatigue between both nasal cavities

$$
\begin{gathered}
\text { By } \\
\text { A. KOMATU } \\
\text { From the Department of Oto-Rhino-Laryngology Showa School of Medicine }
\end{gathered}
$$

(Director: Prof. T. Yamamoto M.D.)

I made a series of studies on the olfactory fatigue.

The results were summarised as follows:

Part I: The degree of threshold shift, examined by change of either duration time of smell stim. ulus or density of smell substance, was generally irregular. No regulation on the olfactory fatigue was recognized. Thus necessity and possibility of the new method of the examination of the olfactory fatigue was demanded.

Part II: Using my new method, named the increasing stimulus method, examinations of the olfactory fatigue were performed on groups of persons normal in health and with various nasal diseases.

Fatigue curves could be devided into 4 types (Type I, I, I, N), and Type I regarded to normal type, $\mathbb{I}, \mathbb{I}$, and $\mathbb{V}$ pathological type. According to the studies, signficant corrlations were found to exist between the chronic nasal diseases and Type $\mathbb{V}$.

Part. III: Examinations of the relation on the olfactory fatigue between both cavities, and of the fatigue curve type of each nasal cavities were conducted. From these results obtained, conclusion was drawn that the localisation of olfactory fatigue would be peripheral.

\section{嗅覚疲労に関する研 究}

\section{第 1 編 嗅覚疲労検査法に関する研究}

第 2 編 連続剌激増加法による㖵覚痩労の研究

第 3 編 左右别嗅覚疲労に閜学る研究

\section{昭和医科大学耳奥咽喉科学教室（主任：山本常古教授）}<smiles>[As]=[Te]</smiles>

\section{目次}

第 1 編 嗅喾疲学検査法飞関する研究

第 $\mathrm{I}$ 章 緒 言

第 2 章 実験材料並びに実験方法

第 1 節 負荷嗅素量との関係

第 2 節 負荷時間之の関係

第 3 章 实験成績並びに総括

第 1 節 負荷嗅素量との関係

第 2 節 負荷時間との関係

$\begin{array}{lll}\text { 第 } 4 \text { 章 } & \text { 考 } & \text { 按 } \\ \text { 第 } 5 \text { 章 } & \text { 結 } & \text { 諭 }\end{array}$

第 2 編 連続刺激增加法に上る嘎觉疲労の研究

第1 章 緒言

第 2 章 実験材料並びに実験方法

第3 章 実駼成縝並びに総括

第 1 節 正常者実験成禎

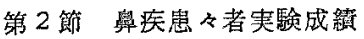

第 4 章 考按 


\section{第 5 笪 結論}

第3 編 左右別㖵覚痩学に関する研究

第 1 算 緒 言

第 2 章 実験材料型びに実験方法

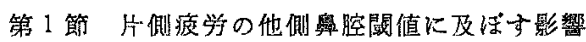

第 2 節 正常者左右別嗅覚疲学实験

第 3 節 奥疾患 \&者左右別㖵覚疲学実験
第 3 章 実験成縝並びに総括

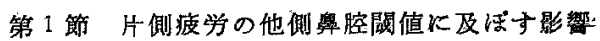

第 2 節 正常者左右別実験成縝

第3 節 畺疾患々者左右別実驗成績

$\begin{array}{llr}\text { 第 } 4 \text { 章 } & \text { 考 } \\ \text { 第 } 5 \text { 墇 } & \text { 結 } \\ & \text { 参考芬献 }\end{array}$

\section{第 1 編 嗅覚疲労検查法に関する研究}

\section{第1音 粕兽}

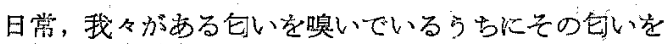
全く感じなくなる事は雁々経㧎する現象である。この現

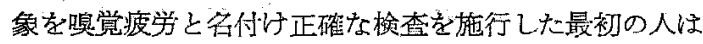
E. Aronsohn (1886年)である。搝刺激の强さと嗅感

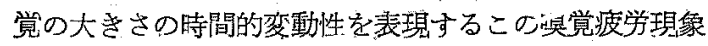

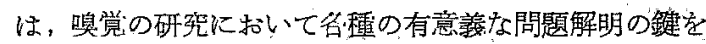

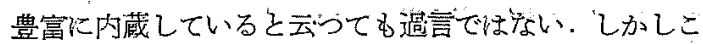

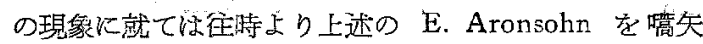
ŁLて, H. Zwaardemaker, J. Hermanides, Elsberg,

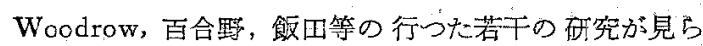

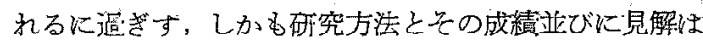
区トで必ずしも一致していないばかりでなく，何等の亲 統的砳究法の糸口五得られていない、一般に喚覚に聴覚 や視覚等のよらな代の感賞に上較して々の物理学的万至

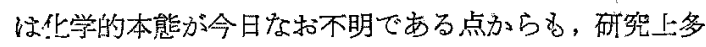

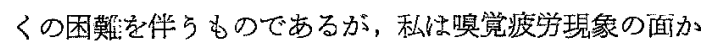

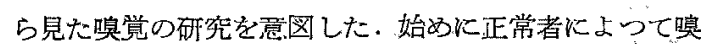

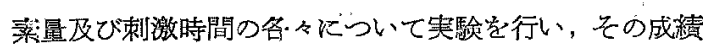
をるとして諸先人の方法を检討したので報告する。

\section{第 2 章 実験材料並びに実験方法}

第 1 節 負荷咱菜量との関你

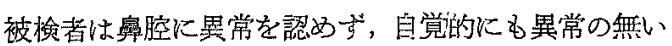
正常人里子. 6 名，女子 4 名計 10 名とした。年令は 23 才 から28才に潘つている。実験方法はへトロベリーエッ 女ンスの倍数稀釈系列を使用した．即ら一定容量の嗅菜

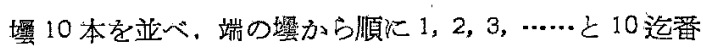

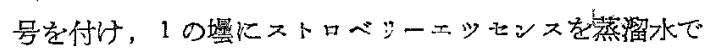

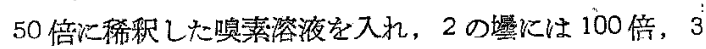

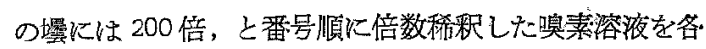

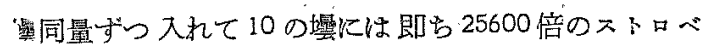

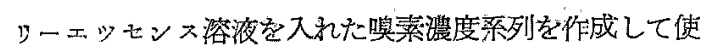
用した、なお，本矿究に和ける以下の等实験には総てこ
のストロベシーエツ七ンスの倍数稀粎柔列を用いた。本 系列を用いての最小刺激闘值测定法心先す被检者に閉腿

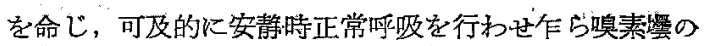

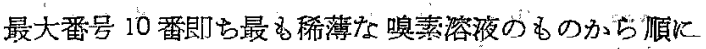

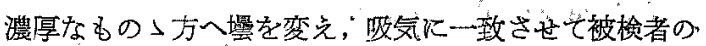

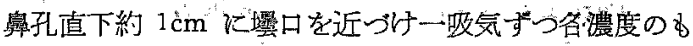

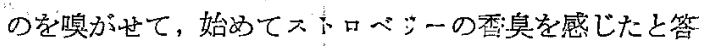

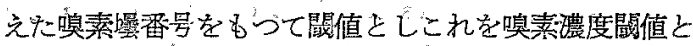

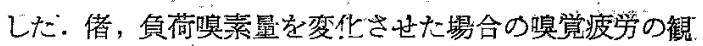

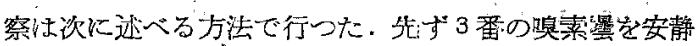

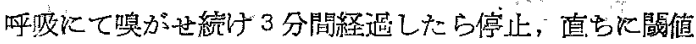

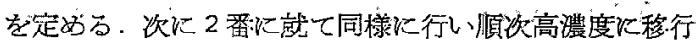
する、な特，特に50倍よりも濃厚なものとして，25倍 から原液に至当迄㙾数を 5 本追加し灙度順に0 (25倍)，

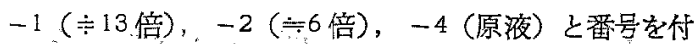
け使用した。”然検查は間に 2 分間以上の休止時間を置き 前に顀荷された刺激の影響が後の检查に及ふのを排除し た、同一人の検查は24時間後に行つた。，及，女性は総 て月経時を避げて施行した。

第 2 節 負荷徍間之の関倭

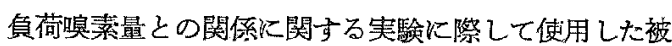

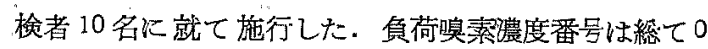
番即名 25 倍溶液とし，負荷時間は 1 分， 2 分，4分，6 分，8分，10分とした。即ら被検者に正常呼四で0番の

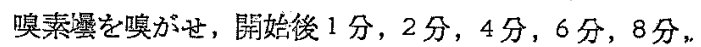
10 分後に出ける濃度閾值を測定した。

\section{第3 章 実験成績並びに総括}

第 1 節 急荷喚素量亡の関係

本実験及び第 2 節の実験に尗いて使用した被検者 10

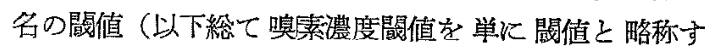
る）は全例 8 であつた，实跧成續は第 1 表に示す通りで

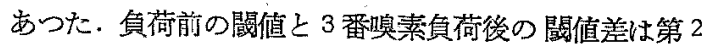
表に示す通りで閾值差の少いもの」例数が多く，又閶值 
第 1 表

\begin{tabular}{|c|c|c|c|c|c|c|c|c|c|c|c|c|c|}
\hline 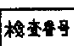 & E. & & 年令 & & & & 3 & 勳 & $\frac{P}{1-1}$ & & & -4 & 最大差 \\
\hline No. 1 & I.M. & 우 & 26 & 8 & 8 & 8 & 8 & (7) & 7 & 7 & 8 & 8 & $8 \sim 7$ \\
\hline No. 2 & M.O. & 今ิ & 26 & 8 & 8 & 7 & 6 & 6 & 5 & 6 & (4) & 5 & $8 \sim 4$ \\
\hline $\mathrm{No} .3$ & AK & $\hat{\delta}$ & 24 & 8 & 6 & 5 & 5 & 4 & 4 & 2 & (1) & 1 & $8-1$ \\
\hline No 4 & A.I. & 우 & 24 & 8 & 7 & 5 & 4 & 4 & 3 & 3 & (1) & 1 & $8 \sim 1$ \\
\hline $\mathrm{No} 5$ & N.O & 㐁 & 26 & 8 & 7 & 6 & 6 & 4 & 3 & 2 & 2 & (1) & $8 \sim 1$ \\
\hline No. 6 & MK & 杏 & 27 & 8 & 8 & 7 & 7 & 5 & 4 & 4 & (3) & 3 & $8-3$ \\
\hline No. 7 & AS. & 8 & 25 & 8 & 8 & 8 & 6 & 5 & 3 & 4 & (2) & 2 & $8 \sim 2$ \\
\hline No. 8 & $\mathrm{H}, \mathrm{K}$ & 응 & 28 & 8 & 6 & 5 & 4 & 4 & 4 & (3) & 4 & 3 & $8-3$ \\
\hline No. 9 & MK & 우 & 25 & 8 & 5 & 3 & 2 & (1) & 1 & 1 & 1 & 1 & $8 \sim 1$ \\
\hline No.10 & T.S. & 우 & 23 & 8 & 7 & 5 & 3 & 3 & 2 & 1 & (0) & 1 & $8-0$ \\
\hline
\end{tabular}

\begin{tabular}{|l|l|l|l|l|l|}
\multicolumn{2}{c}{ 第 } & \multicolumn{2}{c}{ 表 } \\
\hline 閾㑬差 & 0 & 1 & 2 & 3 & 4 姜 \\
\hline 例数 & 4 & 3 & 2 & 1 & 0 \\
\hline
\end{tabular}

第 3 表

\begin{tabular}{|l|l|l|l|l|l|l|l|l|l|}
\hline 最大差 & 8 & 7 & 6 & 5 & 4 & 3 & 2 & 1 & 0 \\
\hline 例 数 & 1 & 4 & 1 & 2 & 1 & 0 & 0 & 1 & 0 \\
\hline
\end{tabular}

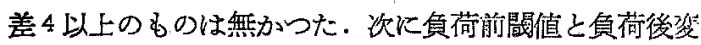
動閔値之の最大差は第3 表に示す通り差の大なるもの」 例数が多い傾向にあつたが No.1 の如く差が1のもの も見られた，最大差を示した負荷嗅素濃度番号値心0番 が 2 例， -2 番が 1 例， -3 番が 6 例， -4 番が I 例, 他は 1 例む無くほざー3 番で最高の疲学に達したと思わ

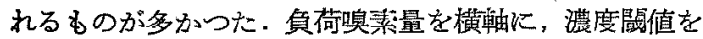
縦軸にとつたダフフを画いて出者の関傒を調へると，全 例については第 1 図に示す通りである，即ら䝯荷嗅素量

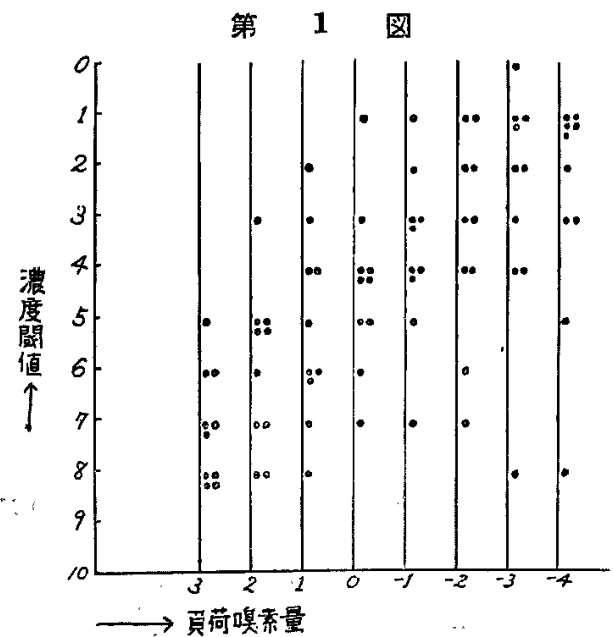

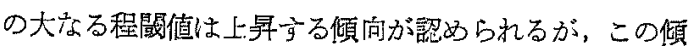
向む確然とはして敊らず，成續の分布相相当の分散が存 するのも雪実である．この事実は第 2 図に例示する 2,3 の例のグシフで一阅明瞭である. No. 1 は砝んどグフフ

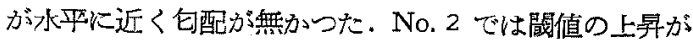
途中で一度下降を示した. No. 5 'の如く一様のト茅包配 を示寸るのも見られたのに反し，No.9の如く上算途中 でグンフが屈折し以後水平となつた例もあつた。なお， 同一人について実験日を变光，3回行つた成續は第3 図 に示す通りで全回同样なグラフとなつたものは少なく (No. 5).匂配の変伦乃至はダ ワフ型の変化を多少とむ示 すものが多かつた (No. 1)，(No.7).
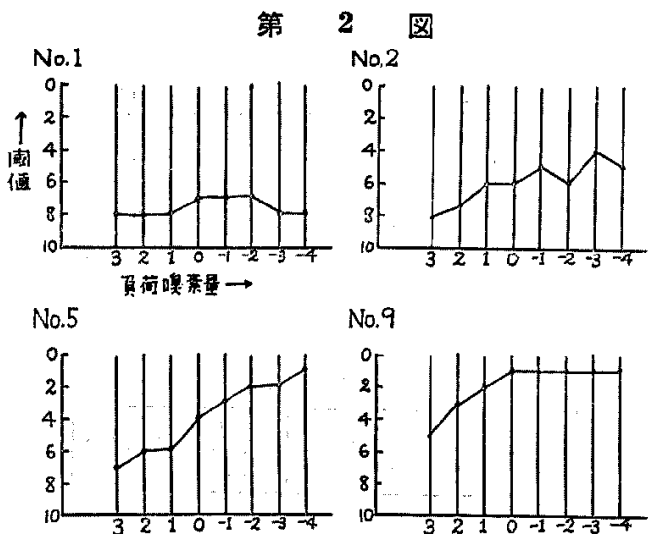

No. 9

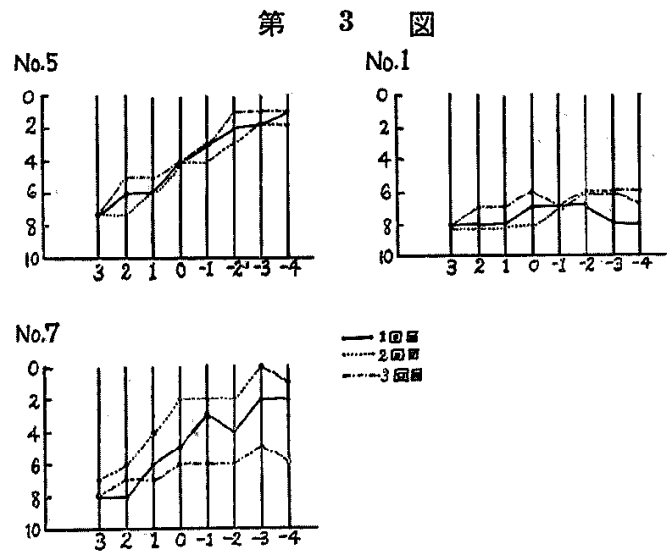

第 2 節 負荷時間上の関掭

全例の实駼成䌮は第 4 表に示す通りであつた。負荷前

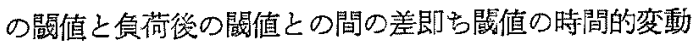
の大きさを頻度別に表示すると，第5 表に示す通りで， 負荷時間 1 分では閶値差 0 即ち变動のないるのが 2 例あ 


\section{第 4 表}

\begin{tabular}{|c|c|c|c|c|c|c|c|c|c|c|c|}
\hline 搔育番号 低名 & 生 & & & & & & & & & & 最大管 \\
\hline No. 1 A.I. & 우 & 24 & 8 & r & & 7 & 6 & 5 & 4 & 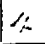 & $5-4$ \\
\hline No. 2 MO & $\hat{o}$ & 26 & 8 & $\theta$ & & ; & 5 & 3 & 2) & 2 & $8-2$ \\
\hline \begin{tabular}{l|l|l} 
No. 3 & HK \\
\end{tabular} & $\hat{3}$ & 28 & 8 & 6 & & 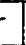 & \% & 3 & (2) & 2 & $8 \sim 2$ \\
\hline \begin{tabular}{l|l} 
No. 4 & IIM \\
\end{tabular} & 오 & 26 & 8 & 6 & & 5 & 5 & 5 & 5. & (4) & $8 \sim 4$ \\
\hline No. 5 A.S. & 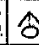 & 25 & 8 & 6 & & 5 & 4 & (2) & 3 & 3 & $8 \sim 2$ \\
\hline No. 6 T.S. & 우 & 23 & 8 & 8 & & $?$ & 6 & 5 & 4 & (3) & $8 \sim 3$ \\
\hline \begin{tabular}{|l|l|} 
No. 7 & $\mathrm{MK}$ \\
\end{tabular} & 오 & 25 & 8 & & & i & 2 & 0 & -1 & -1 & $8 \sim-1$ \\
\hline No. 8 N.O & 令 & 26 & 8 & ? & & & 3 & 1 & -1 & (-2) & $8 \sim-2$ \\
\hline No. $9 . \mathrm{AK}$ & 8 & 24 & 8 & 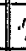 & & & 3 & (1) & 1 & 1 & $8 \sim 1$ \\
\hline No. $10 \mathrm{MK}$ & 8 & 27 & 8 & $\varepsilon$ & & 7 & 6 & (5) & 6 & .5 & $8 \sim 5$ \\
\hline
\end{tabular}

\begin{tabular}{|c|c|c|c|c|c|c|c|c|c|}
\hline & & \multicolumn{2}{|c|}{ 表 } & & & \\
\hline 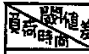 & 0 & 1 & 2 & 3 & 4 & 5 & 6 & 7 & 部 \\
\hline 1 分 & 2利 & 3例 & $\begin{array}{l}5 \text { 例 } \\
50,5\end{array}$ & 0 & 0 & 0 & 0 & 0 & 10 湆 \\
\hline 2 分 & 0 & 3峢 & $\frac{2 \text { 例 }}{2}$ & 40, & $\begin{array}{ll}\text { I列 } \\
\end{array}$ & 0 & 0 & 10 & 10 㪴 \\
\hline 4 分 & 0 & 0 & 3咧 & Z & 2例 & 2例 & 1例 & 10 & 10 (bin) \\
\hline
\end{tabular}

\begin{tabular}{c|c|c|c|c|c|c|c|c|c|c|}
\multicolumn{1}{c}{ 第 6} \\
\hline 表大美 & 10 & 9 & 8 & 7 & 6 & 5 & 4 & 3 & 2 & $\overline{1}$ \\
\hline 例数 & 1 & 1 & 0 & 1 & 3 & 1 & 2 & 1 & 0 & 10 \\
\hline
\end{tabular}

第7表 闘值上年の最高に達する時間の頻度

\begin{tabular}{|l|c|c|c|c|}
\hline 曋荷時国 & 6 分 & 8 分 & 10 分 & 計 \\
\hline 㤡数 & 3 & 4 & 3 & 10 \\
\hline
\end{tabular}

り，䦪値差 2 以上のむのは 5 例 $(50 \%)$ 見られ，2 分で

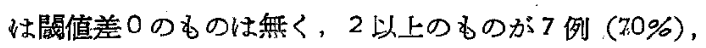
4 分では 2 以上のものが 10 例 (100\%) 即ら 全例となつ ている. 次に䦔値の最大差即ち負荷後の關值上昇の最大 值を頻度別に見ると第6 表に示す通り閶值上昇が僅か 3 のものから10のもの迄活よ゙平均している. 最高汇達す る負荷時間の頻度は第 7 表に示寸通り 6 分が 3 例, 8 分 が 4 例，10 分が 3 例であり，結局 10 分末満で 7 例 70 \%) が最大の閔值上景を示している.負荷時間を横軸に

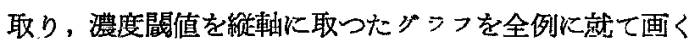
と第 4 因に示通り之なる，即ち負荷時間の大なる程間 值の上昇が大となる傾向が認められるが，一方顀荷時間 の太なる程閶值の分散が大となつている。各例に就て作 成したグラフを例示寸ると第5 図に見られる如く。No. 3 は負荷時間 1 分で確実に闒值上畀をきたし 2 分，4 分，
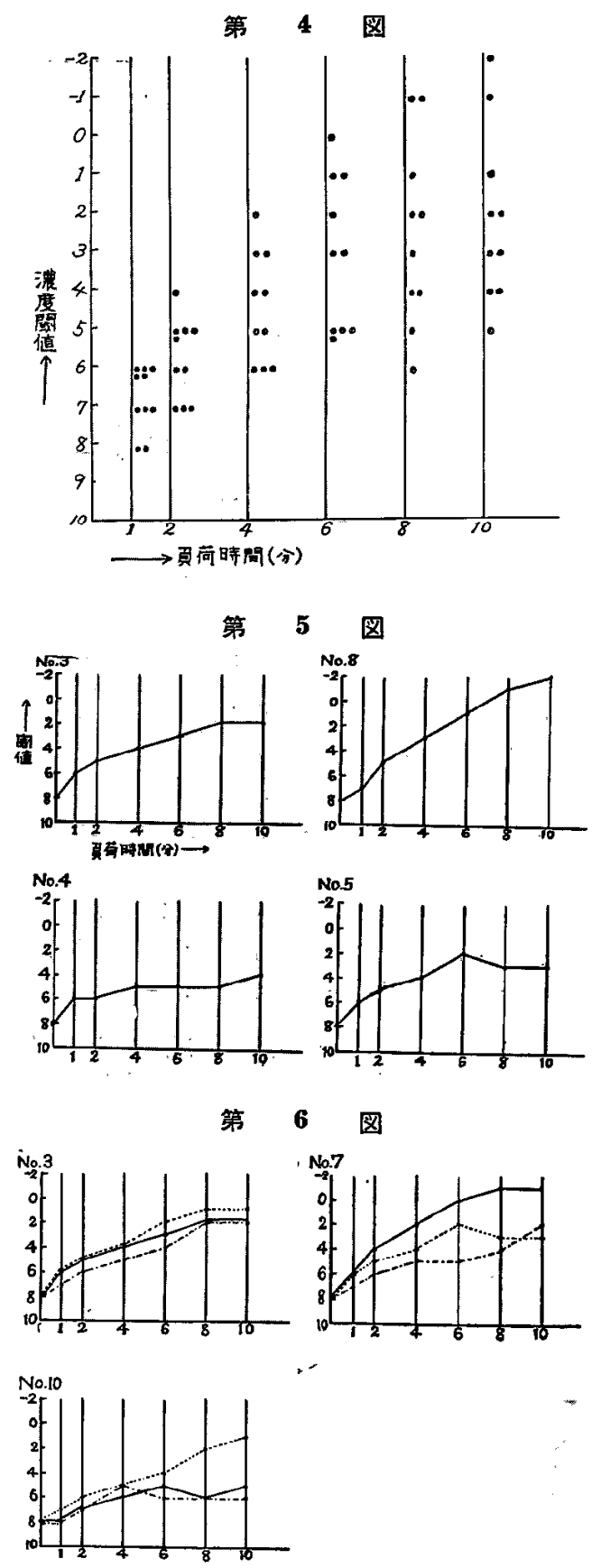

6 分，8分では夫々平均した閔值上杽を示しておりグ フは住よ゙ー定の匂配をいつた㨁線に近いるのであるが， このようなグラフを示した例は少数记過ぎず 3 例（30 \%)であつた。他性匂配が著しく変化したり，グラフが 


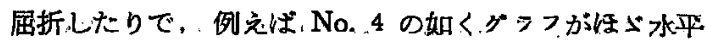
になるるのや No.. 8 のように甚しく急な 句配を示する の, 又は No. 5 のように凸形の屆折を示すものが種 見られた。同一人に就て実験日を变え了回施行した成績 は第6図に示す通りで全回同様のグンフとなつたもの

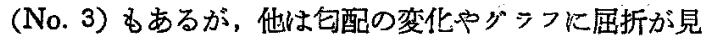
られたりした (No.7), (No、10).

\section{第4章考按}

1886 年 E. A ronsohn が始めて，通常，嗅覚の疲労 と名付ける現象について正確な検查を施行した。 即ち懙 菜を入れたフシスニを鼻の下に保持しつ〉嗅いでいると ある時間後には，その嗅感悄失するように思われると し，それに要する時間は嗅䒺の檑類に応じて種々である と述べた。

H. Zwaardemaker は精密な結果を得るために，一 定の香気を嗅がせる 時間を $15 ， 30,45,60$ 秒等に変化さ 世, 夫^の場合の嗅覚闒值を测定して, 疲労曲線を画 き，刺激時間の長い程疲労の程度が增して行くとし， 叉 刺激の強い程, 疲労が早く起るとした。

J. Hermanides は疲労の影響の下に生ずる反応時間 の延長を検査したを述べている：

Woodrow は特別な測定装置 (嗅敩計)を作製したが， これを使用して非常に精密な方法で実験を行つた結果， 疲労に上る嗅感の消失速度は, 一定時間中に器官に他れ る咱菜分子数に比例する事を発見したと報告している。

本邦江いては百合野が，弱い嗅刺激に上つて無感覚 と成つた嗅覚も，それ以上の強い嗅束激をるつてすれば 更に反応を呈する現象を数值を挙げて説明した.

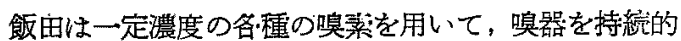
に刺激して嗅感が消失するや否や刺激を停止し，一定の 休止時間の後更に再び当該嗅茅机より刺激を与え，この 事を反覆して嗔覚の疲労する状況を検查した。その結果: 疲労性鮕覚脱失の起る時間は正常人嚊器においても等し くなく，又同一人に和いても比儤的著しい長短があると

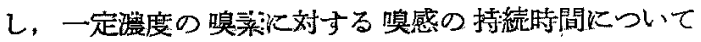
も，休止時間を隔て〉の毎回の变化は漸次短縮するが， その状況は各人によつて異る上述べている，更に休止時 間短縮の影響之，嗅亲浱度を高めた場合の影響について も観察して、これ等の場合も矢張り個体差及び毎回の差 があり一定しないと述へ，他方，氏の方法によつた場合 の正常人に和汓る疲労恢復時間は 4 分万至 5 分以内であ るとしている。

以上の如く通常，嗅覚疲労と称されている嗅刺激持流
による嗅覚䦭値の上牙乃至は嗅感消失現象については非 常に古くから幾人かの研究者達によって夫々多様な研究 方法とその成績に基く見解が発表されている.今回は特 K H. Zwaardemaker の分類した同種疲労之異種疲労 (homonyme Ermüdung u, heteronyme Ermüdung)

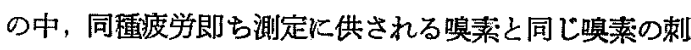
激による同楎の臭感の鈍床の現れとしての疲労を取扱つ ているが，乘に角現在迄火 該現象に就てその本態は勿 論，諸所見に関しても一定の結論が得られていない：末 だ該珼象の 周辺を䀧中模索しているに過ざない感があ る。聼覚括ける疲労現象の研究が多彩でしかも相当梁

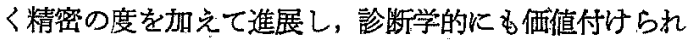
ているのに比し，哭覚に出いては上述の現状に止つてい るのは聴覚が諸種の 電気生理学的あるいは電子工学的 （例壳ばオージオメーター）研究手段を有しているのに 区して，搝覚生理に関する未解決の分野が余りに大きす ぎる事亚びに嗅覚それ自体が有する不可避な性質（呼吸 に随伴する点，嗔菜が拡散し又付着する点等）から研究 方法化多くの困難が付きをとうためである。

乙かし乍ら該現象によつて嗅刺激の強さと嗅感の大き さ即ち喚覚感受性の時間的関保を知る事は㖵覚の本態究 明の上に更更に嗅覚障碍の診断に対し一つの有力な手段 となり得ると確信するので私は今回の研究を行つたので ある、即ち私の行つた垁験成績から得られた知見を述べ る之次のようになる。先す刺激として与文る喚菜の濃度 换言すれば一定時間における嗔器门の負荷咱菜量之嗅営 間值上算との関係流ては，第1 表及び第1 图に示す通 クで概して負荷嗅菜量の大なる程間値が上昇する傾穴が 認められた.これは H. Z Waardemaker やWoodrow の述べた結論之一致している，又，負荷唤等量を增大す

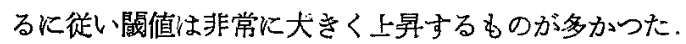
しかし乍ら成綪個々に就て見ると疲労状況は個人差が顕 著で種々の点で一致しないるのが大部分であり，圣同一 人に括いて子毎回一定の結果が得られながた。この点 は飯田む同じ見解住つている，次に負荷時間之閶值上 昇との関係に就ては第 4 表及び第 4 図に示す通りで, 負 荷時間の大なる程間值上䔣が大上なる傾向が認められる が, この点は一部 H. Z waardemaker の得た知見と類 似している. 更に有意の简值上昇は活よ゙ 2 分万至 4 分で 起る等が判明し, 又大部分 8 分で最高の䦭值上戒を示し た、しかしこの場合も倜人差及び同一人における变動が 著しく一定のグンフは得られなかつた，な拉．中村は聴

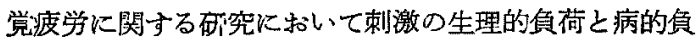


荷の境界に関する Hood の所謂 Critical point（可聴 䦪值上杽度が急激に增加しだす点）を览しく批判しこの 点は検查采件各項のいかんによつて異るとしているが， 私の嗅覚疲労に関する上記二実験においてはこのような 点は全く見出されなかつた。結局以上の知見を綜合して

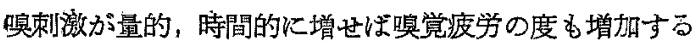
傾向が存する事性認められるが，その状沿は全く定常の 要因に久けるため嗅覚疲学を分析しあるい恰查に供 する事ができない，何故に従来の方法並びに私がこつで 行つた方法では寒験成綘が不定になるかを検討して見る と次記の諸点に基因していると考えられる，(1)喚感は 呼吸伴って惹起するもので実験に当つては吸気に際 乙て起る，吸気之吸気の閶には此蔽的長い時間的間隔が 存し,このために嗅刺激は音刺激の如き連続不断のむの とは成し得ない，一方，疲労の恢復も比較的早い故代 岁る刺激負荷後䦨值を決定する方法は必然的火変動を伴 い不確実を兔れない，(2) 個人的に呼吸数が大きな差を 有寸る場合や同一人に和いても実跧中に呼吸数が変化方 る場合は時間的变動を検查の目的とする疲労実験汇执い て刺激の強さが時間的に変動すると云う点から不合理と なる．故に呼吸数を調整しなければならない（3) 上記

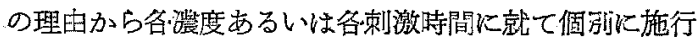
するよりむ，それ等を連絸して綜合した結果を求めた方

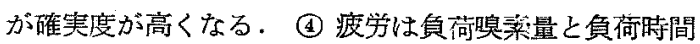
と同者の変代に伴つて変化するがこれ等を一梌查法に統
合すれば変化の度合が 特徽的と成ると考えられる，(5) 正常者の場合は 当初の 辳度關値が一定であるので問題 は無いが，漲度閶值が種々異る場合は嗅刺激る勿論浱度 闖値との関連を無視できない。

以上の諸点を満足させるる検查法が必要となるが私は疲 労時間を連続的に追求する方法によつて負荷時間と負荷 嗅素量両者の变化に則応した新検查法を案出した。その 詳細は第 2 編に打いて述べる。

\section{第 5 章 結論}

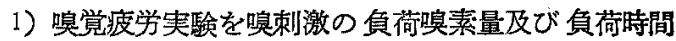
に関して各ヶ正常者 10 名に就て施行した。

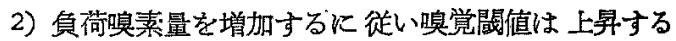
傾向が認められたが，その状況は個人差が著明であり， 又同一人の実験成績も毎回変動した.

3) 負荷時間を延長するに従い鄙覚豆值は上昇する傾 向にあり 8 分で最高に達するすのが比較的多かつたが， 程ヶの点で個人差及び実騟回差が認められ，それ等に就 て一定の要因は発見できなからた。

4) 䏯覚疲労実駼に括ける Hood の所謂 Critical point の如き点は両実験を通じて発現しなからた。

5）従来の報告及び、今回の成續を検討し，嗅覚疲労検 查法の久陌を举け゚てそれ等を满足させる可き条件を備え た激検査法の必要を説いた。

\section{第 2 編. “連続刺激增加法による嗅覚疲労の研究}

\section{第1章 緒言}

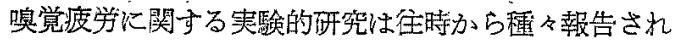
ているが，研究方法と乞の成續並びに气れ基く見解は

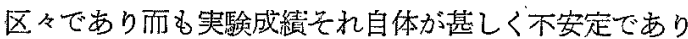
一定の結果や要因が得られていない，第 1 編において私

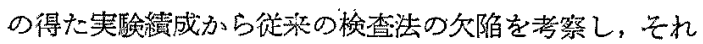

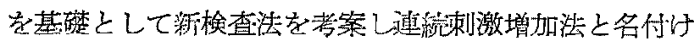
たが本法によつて正常者の嗅営疲学を検查したので報告

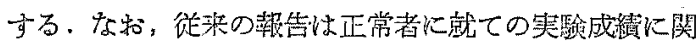
するむのつみであり舆疾㭧時の嗅営疲労に言及していな

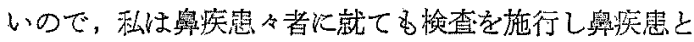

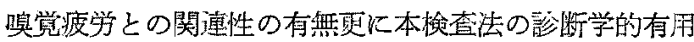
性の加何に迄研究を進好た。

\section{第 2 章 实験材料並びに実験方法}

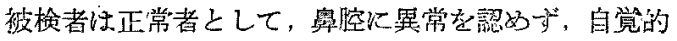

にも異常を訴党ない黑子 18 名, 女子 2 名, 計 20 名を材 数とした。年令は18才から40才に涉っている.

鼻疾患々者は昭和医科学病院耳鼻咽喉科外来を訪れ たすの今中から，16才から38才迄の男子19名，15才 から34才迄の女子 11 名計 30 名を材料とした，

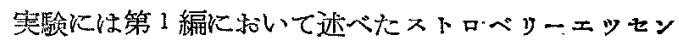
スの倍数稀䣋系列を使用儿，方法住連続刺激增加法に上

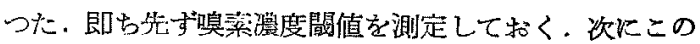

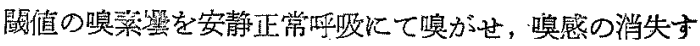

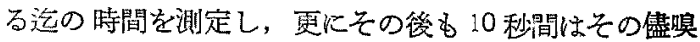

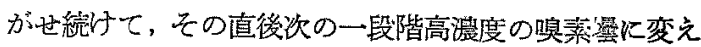
て鮕がせる．この壆です搝感の消尖する迄の時間を測定 し，矢張り嗅感が消尖してから 10 秒間継綂させて更に 一呩階高浱度に変える。このような操作を続けて行う

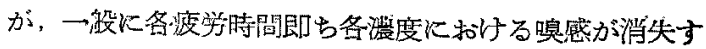


る迄の時間は，順次签度の高いるの」方に移行するに従 い延長して行く傾向があるので 3 分間経過しても嗅感の 消尖しない灢度に達した場合はそそこで停止する事とし た．更に嗅ぐ事を停止した瞬間から時間を計り，20秒

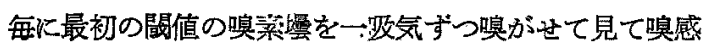
が再び起つた時の時間を゙恢復時間として記録した，成結

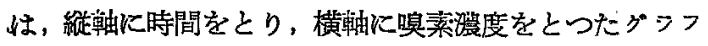
《画き疲労曲線として検討した．なお，予的被険者の安 静持正常呼吸数を計り，メトロノームの振れをそれに合 わせて刻ませ，実験中被検者がメトロノームの刻む音に 一致させて乎吸を行らようにして呼吸数が变化するのを 調整した。

\section{第3章 実呀成績並びに総括}

第 1 節 正常者実験成績並びに総括

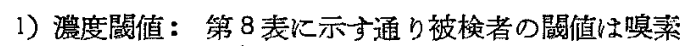

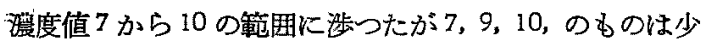
数で, 8 のあのが $70 \%$ あり特多がた。

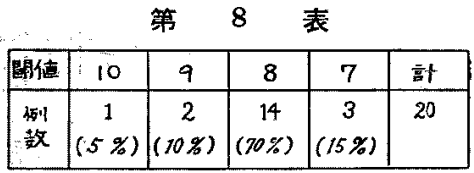

2) 平均疲族時間：各例に就て平均疲労時間の算出空 行つた，即ち全経過に要した時間（但し最終回の 3 分は 疲学時問ではないのでこの3分を隇じた時間)を瑱がせ

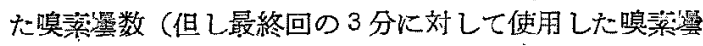
数 1 を減じた数)で除して各疲労時間の平均值を求め た. その成續は第9表に示す通りで，30秒毎に区分し 大結果は 30 秒以上 180 秒迄に啮り，而特に多数例の 占めた時間区分は䡯からた。

\begin{tabular}{|c|c|}
\hline 严均疲労時简 & 例数 \\
\hline $0 \sim 30 \mathrm{sec}$ & 0 \\
\hline $31 \sim 60$. & 5 \\
\hline $61 \sim 90$. & 4 \\
\hline $91 \sim 120$. & 5 \\
\hline $121 \sim 150$ & 4 \\
\hline $151-180$ & 2 \\
\hline
\end{tabular}

3) 恢復時間：1 分每に 区分して例数分布を見ると 第10表に示寸通りで，最 高 7 分以上 8 分末淦の 1 例 があつたが大体 1 分末満の ものから5分迄のものが㴗 ぼ乘均して現れ，その中特 に1 分以上3分末満のむの が多がらた５分以上の\& のは 2 例で極めて少数であ つた。

4) 平均疲労特間之恢復時間との関係：：耐者間の関係
第 I O 表

\begin{tabular}{|c|c|}
\hline 恢復的間 & 例数 \\
\hline 1分未潇 & 3 \\
\hline 1 分 $\sim 23$ 分满 & 5 \\
\hline 2 分 -3 分皐 & 4 \\
\hline 3 分 -4 到。 & 3 \\
\hline 4分〜 5分.. & 3 \\
\hline 5 分 $\sim 6$ 公。 & 1 \\
\hline 6 分 -7 公. & 0 \\
\hline 7 完 $\sim 8$ 分 & 1 \\
\hline
\end{tabular}

を知るために第 11 表を作 成したが各例数は土全般に分 散して見られ特定の分布を 示さなかつた・即ち恢復時 聞の長短と平均疲労時間の 辱短との間には特別の相関 関係を認めなからた。

5) 疲労曲線: 縦軸江疲 労時間を秒でとり, 横轴に 噚索溚度值をとつたグシフ を作成乙各潅度に括ける 夫^の疲学時間を結んで疲 労曲線として観察した.グ

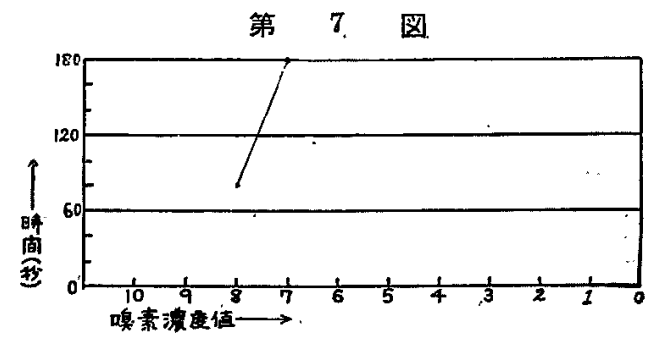

第 8 図

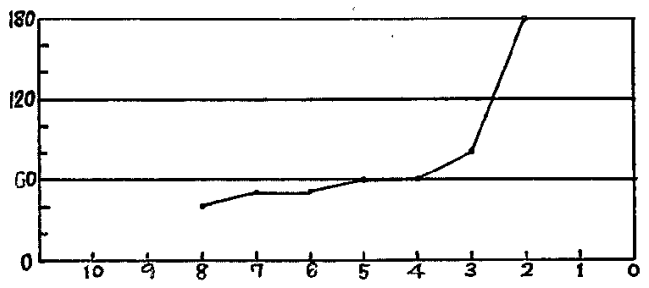

第 9 図

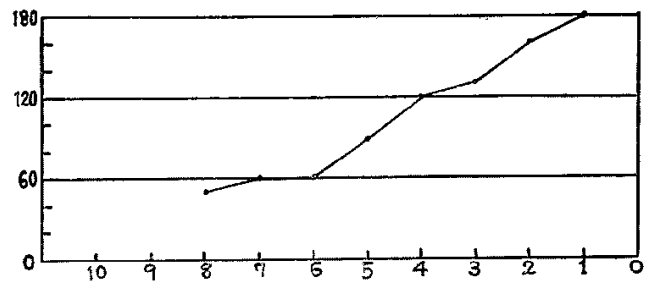

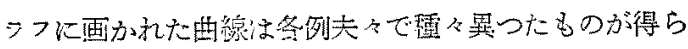

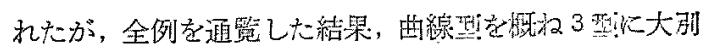
して分類できる承認的た。即ち第7、图に示す検查例 11 の如く閝值附近で急激に 3 分に達寸るるのを1型と

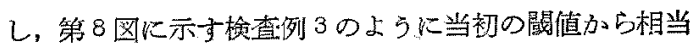


第 11 表 平均疲労時間と性復時間（例数）

\begin{tabular}{|c|c|c|c|c|c|}
\hline 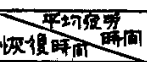 & 稍 20 & $61 \sim 90$ & $91 \sim 120$ & $121 \sim 150$ & $151 \sim-180$ \\
\hline 1分未满 & 例 2 & & & 1 & \\
\hline 1 尔～2分榙 & & & 2 & 3 & \\
\hline $2 \cdot-3 \cdots$ & & 3 & 1 & & \\
\hline $3 \div \sim 4 \cdots$ & $I$ & & & & 2 \\
\hline $4: 5 \ldots$ & 1 & 1 & 1 & & \\
\hline $5 \cdots 6 \ldots$ & & & 1 & & \\
\hline $6: \sim 7 \cdots$ & & & & & \\
\hline $7 " \sim 8 \cdots$ & $i$ & & & & \\
\hline
\end{tabular}

数離れた镐度値迄は比較的短い疲労時間を示し而も曲線 は水平乃至は極めて匂配小さく，終末附近に到って急に 大なる匂配を示す型を【型とし，第9 沧の検查例 15 の 如くほよ゙直線に近い極めて緩徐な增加を示して遂に 3 分 に達する漸増型を而型とした。

6)グフフ型と恢復時間との関係：全例を上述のグラ フ型に従つて分類して見るとI型を示したものは12 例 で非常に多く60\%，II型のものは 6 例で 30\%，III 型! ば2 例で㒖かに $10 \%$ であつた。各型に就て恢復時間を 比較すると第 12 表の通り，I 型では恢復時間が 3 分末 満のものが圧倒的に多く，I型は 3 分から5 分迄のもの が大部分であり，四型では 5 分以上を示した。

第 12 表

\begin{tabular}{|c|c|c|c|c|}
\hline 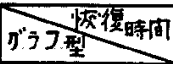 & 1分未満 & 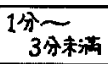 & 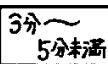 & 5分㛇上 \\
\hline$I$ 型 12 例 & 3 & 8 & 1 & \\
\hline 6树 & & 1 & 5 & \\
\hline III型 2例 & & & & 2 \\
\hline
\end{tabular}

第 10 図

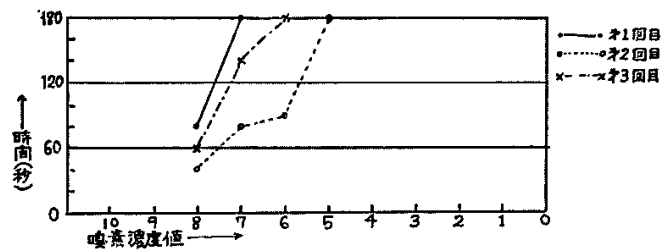

7) 同一番の疲労型変動：同一人について毎回汪ら゙同 様な状態で同一跱刻に 検查できたもの 4 例の 検査成䅡 は，各人について 3 日間ずつ施行した結果，平均疲労時 閒は毎回の検查に際して夫々相当の变動を見たが，恢復
時間は毎回ほよ゙近似の值が得られる傾向にあり、グラフ 型については全例が 1 型であつたが，3 3 例は钽回1 型を 示し第 10 図化 例示する 1 例のみが 1 回だけや小型火 類似の型を示した．即ち恢復時閪とグシフ型は毎回変化 しなかつたと云ら事になる：

第 2 節 奥疾患々者実験成猜並びに総括

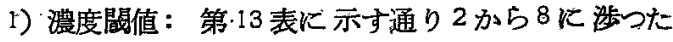
が正常值 $(8,7)$ を得たものは，8が 4 例，7が 3 例で計 7 例 (23.3\%) であつた. 5 以下のものは 5 が6 例, 4 が 5例, 3 が 7 例, 2 が 1 例で計 19 例 (63.3\%) であつた。

第 13 表

\begin{tabular}{|c|c|c|c|c|c|c|c|c|}
\hline 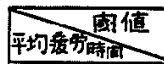 & 8 & 7 & 6 & 5 & 4 & 3 & 2 & 棓 \\
\hline $31^{2}-60^{* 2}$ & 2 & 1 & 2 & 2 & & 2 & & 9 \\
\hline $61^{\prime \prime} \sim 90^{\prime \prime}$ & & 1 & 1 & 3 & 3 & 2 & & 10 \\
\hline $91^{\circ} \sim 120^{\circ}$ & 1 & 1 & & 1 & 1 & 2 & 1 & 7 \\
\hline $121^{\circ} \sim 150^{\circ}$ & 1 & & 1 & & 1 & & & 3 \\
\hline $151^{\circ} \sim 180^{\circ}$ & & & & & & 1 & & 1 \\
\hline 計 & 4 & 3 & 4 & 6 & 5 & 7 & 1 & 30 例 \\
\hline
\end{tabular}

2）平厸疲労時間：第 13 表に示す通り 30 秒毎に区分 した結果汢 31 秒以上 180 秒飞渉り特に 120 秒末満のも のが計 26 例 (86.7\%) を占めた。

3）閶值と平均疲労時間との関保：第 13 表に示过通 り閔値の高低之平均疲労時問の長短との問には特別の関 係認められず备例数は特定の分布を示さなかつた。

第 14 表

\begin{tabular}{|c|c|c|c|c|c|c|}
\hline 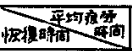 & $31^{\circ} \sim 60^{\circ}$ & $6 \% \sim 90^{\circ}$ & $91 \div 120^{\circ}$ & $\mid 22 \div \sim 150$ & $251 \approx 780^{\circ}$ & 計 \\
\hline 1分未满 & 0 & 1 & 0 & 0 & 1 & 2 \\
\hline 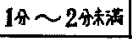 & 1 & 1 & 0 & 2 & 0 & 4 \\
\hline $2^{\prime} \sim 3$ & 0 & 1 & 1 & 0 & 0 & 2 \\
\hline $3^{\prime} \sim 4^{\prime}$ & 2 & 1 & 2 & 0 & 0 & 5 \\
\hline $4^{\prime} \sim 5$ & 0 & 2 & 2 & 1 & 0 & 5 \\
\hline $5^{\prime \prime} \sim 6^{\prime \prime}$ & 2 & 0 & 0 & 0 & 0 & 2 \\
\hline $6^{3} \sim 7^{\prime}$ & 2 & 1 & 1 & 0 & 0 & 4 \\
\hline 7分以上 & 2 & 3 & 1 & 0 & 0 & 6 \\
\hline 塾 & 9 & 10 & 7 & 3 & 1 & 30 \\
\hline
\end{tabular}

4）恢復時間：第 14 表の如く 1 分毎に区分した結果 は1分末満のものから7 分以上のもの迄に啮つて分散し ていた.

5) 平均疲学時間と恓復時間との 関保：第 14 表火示 
す通りでこの成績からは雨者間即ち恢復時間の長短と平 均疲労時問の長短の間には特定の相関々你を認め得なか つた

6) 疲学曲線：前節の正常者疲労曲線に指けるダラフ 型，I型，II 型， II 型のいずれにも分類できないダシフ 型を示するのがあつた。即ら第11図に示す検查例 8 の

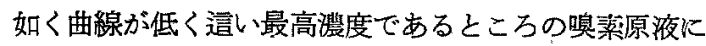
至つてもな和了分に達しなからたものがあつた。これは II 型乃至は III 型の変型とも見られるが分類上 IV 型とし た. 第 15 表並びに第 16 表に示高通り【型は 7 例，II型 は 14 例，II型は 4 例，IV些は 5 例であつた。

第 11 図

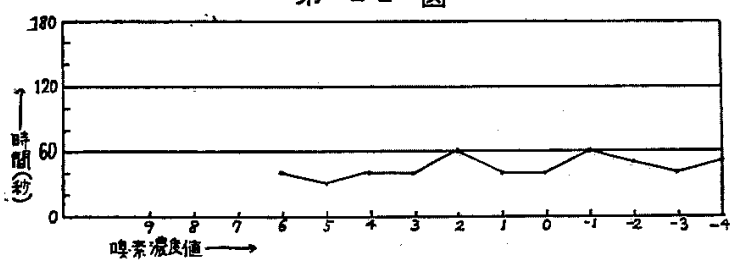

第 15 表

\begin{tabular}{|c|c|c|c|c|c|c|c|c|c|c|}
\hline 型通值 & 8 & 7 & 6 & 5 & 4 & 3 & 2 & 計 & $\%$ & 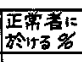 \\
\hline I 型 & 1 & 1 & & 1 & 1 & 3 & & 7 & $23 \%$ & $60 \%$ \\
\hline II 型 & 2 & $I$ & 3 & 3 & 3 & 2 & & 14 & $47 \%$ & $30 \%$ \\
\hline 正型 & & $I$ & & 1 & 1 & & & 4 & $13 \%$ & $10 \%$ \\
\hline N型 & $I$ & & 1 & 1 & & 2 & & 5 & $17 \%$ & $0 \%$ \\
\hline 計 & 4 & & 4 & 6 & 3 & 7 & & 30 例 & & \\
\hline
\end{tabular}

第 16 表

\begin{tabular}{|c|c|c|c|c|c|}
\hline 疾患各 & I 梨 & II 望 & III 型 & 清型 & 言十 \\
\hline 慢性副鼻脿资 & 1 & 5 & 3 & 2 & 11 \\
\hline 萎紡性算炎 & 0 & 0 & 0 & 1 & 1 \\
\hline 肥厚性算炎 & 0 & 3 & 1 & 1 & 5 \\
\hline 急性㢣炎 & 4 & 3 & 0 & 0 & 7 \\
\hline 鼻中陧弯曲症 & 2 & 3 & 0 & 1 & 6 \\
\hline 尌 & 7 & 14 & 4 & 5 & 30 \\
\hline
\end{tabular}

7) グラフ型と閾值との関係：第 15 表の如くとなり

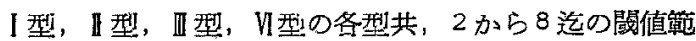
囲のものが夫々ほら平垤して分布し特別の関係は認めら れなかつた。

8）疾患とグラフ型との関係：総数 30 例の中，慢性 副鼻腔炎䍜患々者注 11 例，慢性菱縮性鼻资患者は 1 例， 慢性肥厚性奥炎のみを認める患者は 5 例, 単純なる急性 番炎患者は7 例，鼾中隔緲曲症のみの患者は6例であつ

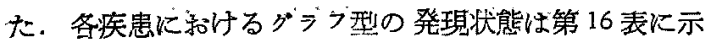

す通りでI型は慢性副鼾腔炏に1例すつたが他は急性番

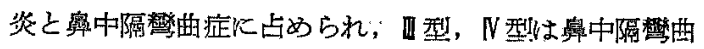
症に 1 例見られた他は総て慢性疾患によつて占められ，

I型は全疾患にほざ平均して見られた。

\section{第 4 章 考按}

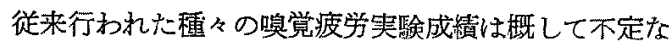
ものが多くいずれの方法による成績も全く定常の爱因に 欠けるために嗅覚疲学を分析しあるいは検查に供する事 ができない，その原因を考察すると第1編に記述した 5 点に基くるのである. 即ち (1) 嗅感は呼吸に伴つて起る が呼吸には時間的にある間隔が多少とも必要であるため 㖵刺激は不連続性であり又即時性が無い，一方疲労の

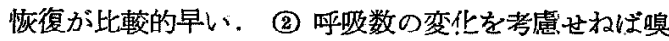
刺激の時間的変動力起る. (3) 上記 2 点から単一嗅刺 激の测定結果性相当の不安定性を伴う（4)負荷嗅索 量と負荷時間の各々が夫々嗅覚疲労に影響を及ぼすの で別個に施行するのは適当でない（5)被検者の検查

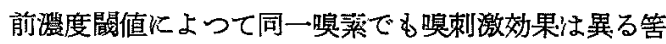
である。

従つて私はこれ等の諸点を考慮の上，連続刺激增加法 を案出したのである. 即ら (1)に対しては一定刺激後一 定時間経逗後の闒值変化測定と云う方法を取らずに，一 定嗅刺激によつてその臭浯に対する嗅感が減退し消失す る迄の時間測定と云ら方法を採用した。（2)に対しては 呼吸数を一定に 保持させる事によつて解溃した，(3) 対しては㖵感消失後次々に高漓度の嗅菜に变え連続して 測定する事により解決したが，この方法は同時に (1) に 対しても解決を与える事になる，(5)の問題は被検者の

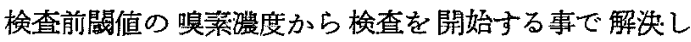

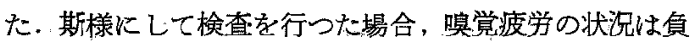
荷咱菜量及び負荷時間の両相に基く変化が統合されて全 体的綜合的に観察類型化する事ができた。

先す゚正常者奏験成績に就て考察して見ると，平坞疲労 時間では個人差が顕著であるが成續に一定の傾向を見な かつた、恢復時間では 3 分以下のものが多く，5分以上の るのは極めて㒖少であつたがこの成績は飯田の報告した 值とはぶ一致している. 平均疲学時間と恢復時間との関 係を調べたが両者間には何等琵むべき相関々倸性無かつ た．疲労時間の変動をグラフに画いた疲労曲線は前述の 如く【型，】型，【型に大きく分類する事ができた.そし

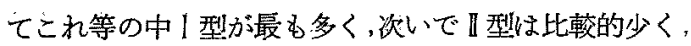
III 型は極めて輽少であらたが更に恢復時間との関係に括 いて，I 型は 3 分未满のものが圧倒的に多く，I型の大 


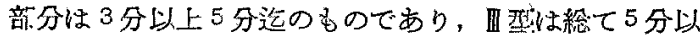

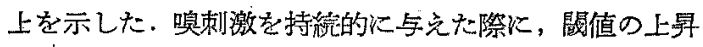
として現れる咱器の感受性低下の難易を, その状態下の 嗅器の疲労性の大小と云う概念をもつて考察すると，I 型は感受性低下が起り難いものであるから疲労性は小で あり，I型はI型行比乙概小疲学性は大であるが祖当高 滞度に括いては比較的急激に一見疲労性の小さい丁 型の 如き曲線に变化する. 即ち高澧度では嗅刺激の增大に比

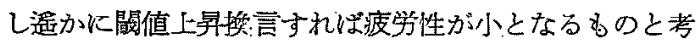
完る、吕型性全く疲労性は大之思わ饥る。恢復時間との 関連も疲労性の点から I 型揤占疲労性の小なるものでは 恢復早く，【型、林型之疲労性の大になるもの程恢復が 幄いと理解できる.同一寊の疲労ダラフ型变動の知見か らも疲労検查炕和いてグラフ型が有意義なものと推考さ 机る。

偖，従来行われなからた鼻疾患々者の唤敩疫労汇関す る実駼は，この連趐刺激增加法によつて検索する事が可 能となり同時に嗅覚疲労の問題解明に対しての莊しい知 見を与えるものである，以下，嶨宾忠々者の实験成綡に 就て考察を扣克ると先ず検查前䦭值は被揄者の種々の梹 患之その病変に対応して 2 加ら8沉啮る広がりを示した

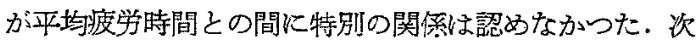
に疲労曲線のグラフ型は I 型，【型，四型の他に正常诸 には見られなかつた代型が相当数認められた．又！型!

II 型， II 型，N型が占める百分率は夫々 $23 \% ， 47 \%$, $13 \% ， 17 \%$ となり第 15 表に示寸如く正常者の場合と大 きな相違を表わしている。䦪值と答ダラフ型との間には 何等の関連を見なかつた。平均疲労時間及び恢復時間に 特別の所見を認めなかつた事，文両者間に認むべき粗 関々侯が無からた事は正常者に就ての成綪の場合と同様 でこれ等の点では率疾患も特別の態度を現わさない事 が判明した。

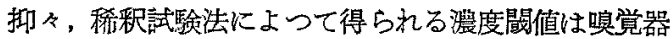
官の感受性の良否を表現するるのであるが，本実駩の成

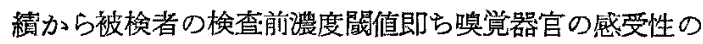
良否と喚覚疲労との間には何等の関連が存在しないもの
之結諭付ける事ができた。な扣この事実は正常者におい

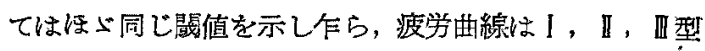
の各型に分類された事からも肯定される。

更に疲労曲線のダシフ型々舅疾患との関係に就て得ら れた知見は，慢性疾患の殆えど総てが II， II， N 型の大 部分を占めたのに反し，急性疾患及び鼻中隔禁曲症のみ がリ型を示したと云う事である。この事実と光に述べた よらに正常者に虾けるグラフ型比率では I 型が大きな

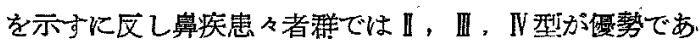
る点から，奥疾患之疲労性との間には相当大なる関係が 存在している事が認められ更に I 型即ら疲労性の極めて 小なる型之疲労性の大なる $\mathbb{1} 、 \mathbb{I I} 、 \mathbb{N}$ 型之は，之の発現 状態加 I 型を正常疲労型とし，他の各型を病的疲労型 とする事ができる，鼻疾喼を有さない所謂正常者に和い。 ての病的疲労型の存在意義は所謂正常者と認定される者

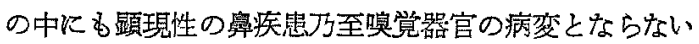
何等かの潜在性の疾海が存在するためにと推考すれは㩆 現性の慢性鼻疾患儿際しては病的疲労型のるのが殆んと 全部を占める事が容易に理解できる。結局，嗅覚疲学に は正常疲学型と病的疲学型があり，病的疲学型の成立に

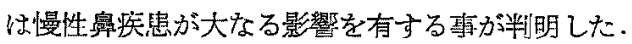

\section{第 5 章 結 論}

1）喚営疲学検查法として 新しく連続刺激增加法を考 案乙，正常者 20 例，鼻疾患名 30 例依就て実験を行つ た.

2）正常者の実験成櫝から，平均疲学時間に関しては 特別の知見は得られなかつたが，疲労曲線は I， I， I 型の 3 型牧分類でき，恢復時間之の間に相関々係を証め。 た。

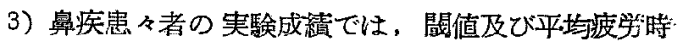
間に関しては特に所見無く、疲労ク゚ラフ型では上記 3 型 に更にN 型を加えたが，疾患との間に特別の関係を認め た。

4）疲労グラフ型は 正常疲学型と病的疲学型に 分類で き，病的疲労型の成立见は㑭疾患特に慢性疾患が大きな 影響を有していると推考した。

\section{第 3 編 左右別嗅覚瘏労に関する研究}

\section{第 1 章 緒 䨐}

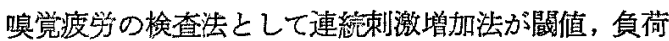
嗅素量, 負荷時間等の変化に対応した疲労状況を, 閔值 上杽に基く搝感消失時問の婵繶的变化によって全体的に
把握するものであり本法によつて疲学型を分類でき，更 に鼻疾患との関連を見出した事は前編に特いて述べた通

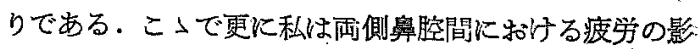

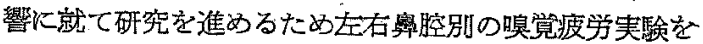


正常者並びに鼾疾腎々者によって施行した，な特，從来 噢覚疲労の位置を末梢とするもの，あるいは中枢とする もの等意見の相違が見られるが，私は本梌查成續に基い てこの点に考察を加えたので，以下記し諸蜸の御批判 を仰ぎ度い。

\section{第 2 章 実験材料並びに実験方法}

第1節 片側疲労の他側鼻腔間值に及ぼす影鄉

被検者は奥腔に異常を認めず自覚的にも異常を訴えな い舅子8名，女子 2 名計 10 名で年令は 23 才から 29 オ 迄の者を用いた．間值測定は嗅意倍数稀釈系列を用い第 1 編に述べた方法によつたが同一被検者で一側外鼻孔を 開鎖する事に上り左右两側別個に行つた．次に右側外鼻 孔を開鎖し左側鼻腔に 0 翻即ら 25 倍嗅柔を 3 分間安静 呼吸にて喚がせ，終了直後右側鼻腔の䦪值を測定した。

第 2 節 正常者左右別嗅覚疲労実験

奥腔に異常無く自覚的にも異常を訴えない18 子から 39 才迄の男子 14 名，女子 2 名計 16 守，32 側就て䇛 歌を行つた，方法は連続刺激增加法之し，同一人に就て 吉側右側㣍今沲行した。

\section{第 3 節 鼻疾患々者左右別唤覚疲労䒠騟}

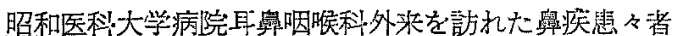
から黒子 18 名, 女子 10 名, 計 28 名を枌湅とし 56 側に 就て实驗老行つた。万方法は前節同様，臬続刺激增加法に より左右別とした。

\section{第3 章 実験成績並びに総括}

第 1 節 片側疲労の他側囱腔閾值に及ぼす影翼

実験成緽は第 17 表に示す通りであつた：主側及び右 側の閖值は 7,8，9の範囲にあり，No. 1 と No. 2 を除

第 17 表

\begin{tabular}{|c|c|c|c|c|c|c|}
\hline \multirow{3}{*}{\begin{tabular}{|l|} 
No. 1 \\
Na查番五 \\
No.
\end{tabular}} & \multirow{3}{*}{\begin{tabular}{|l|} 
氏名 \\
T.G. \\
\end{tabular}} & \multirow{3}{*}{\begin{tabular}{|l} 
性 \\
全.
\end{tabular}} & \multirow{3}{*}{$\frac{\text { 篻令 }}{24}$} & \multicolumn{3}{|c|}{ 閶 值 } \\
\hline & & & & 左 & 右 & 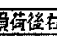 \\
\hline & & & & 8 & 7 & 7 \\
\hline No. 2 & T.S: & $\hat{8}$ & 23 & 8 & 7 & 7 \\
\hline $\mathrm{Na} 3$ & M.K. & 송 & 25 & 7 & 7 & 7 \\
\hline No. 4 . & A.S. & 소 & 25 & 7 & 7 & 7 \\
\hline No. 5 & MK. & $\hat{\delta}$ & 27 & 8 & 8 & 7 \\
\hline No. 6 & $\mathrm{HK}$. & A & 28 & 7 & 7 & 7 \\
\hline No. 7 & A.I. & 9 & 24 & 7 & 7 & 8 \\
\hline No. 8 & N.0. & A & 26 & 9 & 9 & 8 \\
\hline No. 9 & I.M. & 우 & 27 & .7 & 7 & 7 \\
\hline No. 10 & $\overline{A . K}$ & $\hat{8}$ & 29 & 8 & 8 & 8 \\
\hline
\end{tabular}

いて総て2方右同值であつたが No. 1 も Nc. 2 も共にさ

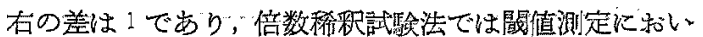
て土1は有意差とは認めないのでこれ等も同値と見做し

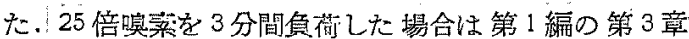
第 1 節に述べた通り相当の閏值上昇をきたすが，本節の 如く完側に同条件で負荷した晹合の在側の閾值は No. 5, No. 7, No. 8 を除いて総て負荷前と全く同值であ つた. しかも No. 5 , No. 7, No. 8 も夫々差は土1 で あつたので有意の差は認められなるつた。

第 2 節 正常者左右別実歌成演

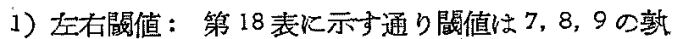

\begin{tabular}{|c|c|c|c|c|}
\hline & & & & \\
\hline 在远 & 9 & 8 & 7 & 該 \\
\hline 9 & $i$ & I & 0 & 2 \\
\hline 8 & 0 & 10 & 2 & 12 \\
\hline 7 & 0 & 2 & 0 & 2 \\
\hline 計 & 1 & 13 & 2 & 16 \\
\hline
\end{tabular}
れかであつたが 16 例中 11 例は尘右の䦪値が全く同値

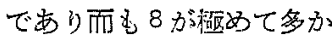
つた.

2) 恢復時間：恢復時間 成蛽を 1 分末渵，1 分以上 3 分末満，3分以上5 分圭

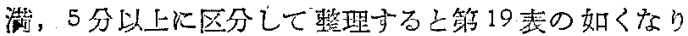

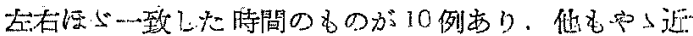

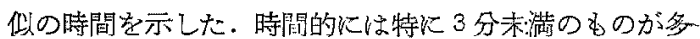
数を占めた。

第 19 表

\begin{tabular}{|c|c|c|c|c|c|}
\hline 右 & 1分未满 & 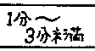 & 3禁余圭河 & 5分以上 & 言十 \\
\hline 1分走渵 & 1 & $I$ & 0 & 0 & 2 \\
\hline 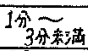 & 2 & 6 & 1 & 0 & 9 \\
\hline 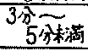 & 0 & 1 & 3 & 1 & 5 \\
\hline 5Atwr & 0 & 0 & 0 & 0 & 0. \\
\hline 計 & 3 & 8 & 4 & 1 & 16 \\
\hline
\end{tabular}

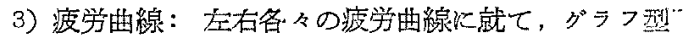
を調べると第 12 図に示す No. 1 の如く，左右共に同じ

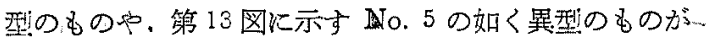
あつた。

第 12 図

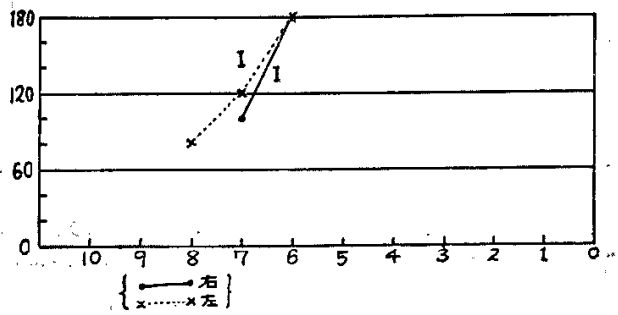


第 13 図

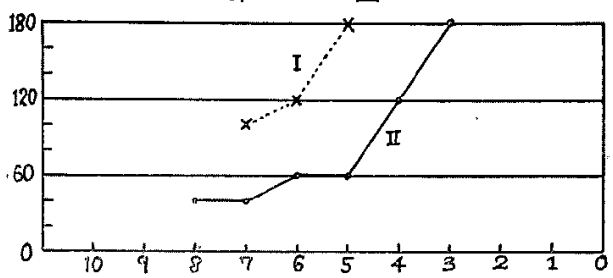

第 20 效

\begin{tabular}{|c|c|c|c|c|}
\hline N & I & II & II & 棓 \\
\hline I & 10 & 1 & 0 & 11 \\
\hline II & 0 & 3 & 1 & 4 \\
\hline II & 0 & 1 & 0 & 1 \\
\hline it & 10 & 5 & 1 & 16 \\
\hline
\end{tabular}

右間のグラフ型の関傜 は第 20 表に見られる通り 16 例中 13 例は文右同型て あり，父の中10例が!型! であつた，異型のるのは 3 例あり।型と】型吕 1 例， II 型と而型が 2 例見られ た。

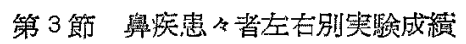

11) 左右闎值： 2 か 58 の範用炕 啮り，28 例中 23 例
第 21 表 \begin{tabular}{|c|c|c|c|c|c|c|c|c|}
\hline 至 & 8 & 7 & 6 & 5 & 4 & 3 & 2 & 0 \\
\hline 8 & 0 & 0 & 0 & 0 & 0 & 2 & 0 & 2 \\
\hline 7 & 1 & 1 & 1 & 0 & 0 & 0 & 0 & 3 \\
\hline 6 & 1 & 1 & 0 & 1 & 2 & 0 & 0 & 5 \\
\hline 5 & 1 & 0 & 2 & 2 & 0 & 0 & 0 & 5 \\
\hline 4 & 0 & 0 & 1 & 0 & 2 & 2 & 0 & 5 \\
\hline 3 & 0 & 0 & 0 & 3 & 1 & 2 & 1 & 7 \\
\hline 2 & 0 & 0 & 0 & 0 & 1 & 0 & 0 & 1 \\
\hline $\mathbf{z}+$ & 3 & 2 & 4 & 6 & 6 & 6 & 1 & 28 \\
\hline
\end{tabular} が 6 以下の高㬊度值を 示した. 左右の閾值間 の関傒は第 21 表の通 りで，主右の閾值が汪 ぼ同值であつたものは 17 例, 垟のあつたるの は11例あった。

2) 恢復時間: 策 22 表以示寸通りで，3分 一未满と 3 分以上では後者の方が前者の約 2 倍以上あつ

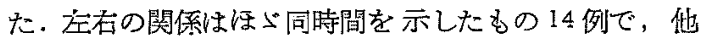

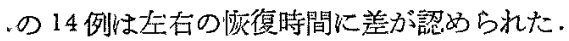

第 22 表

\begin{tabular}{|c|c|c|c|c|c|}
\hline 居古 & 1分未满 & 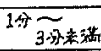 & 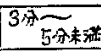 & 5分以上 & 計 \\
\hline 1分末渵 & 1 & 0 & 0 & 0 & 1 \\
\hline 1分分来满 & 1 & 3 & 1 & 1 & 6 \\
\hline 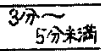 & 0 & 1 & 5 & 4 & 10 \\
\hline 5分以上 & 0 & 3 & 3 & 5 & 11 \\
\hline 言十 & 2 & 7 & 9 & 10 & 28 \\
\hline
\end{tabular}

3）疲労曲線：左右各々の疲学曲線に就て, グシフ型

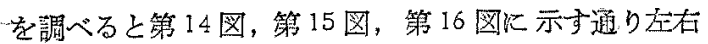
同型のものや異型のものが見られた。攻右間のク゚ラフ型 の関係は第 23 表儿示寸如〈28 例中 15 例は空右同型で 西り，之の中 3 例がI型，6例が型，3例が型，3
第 14 図

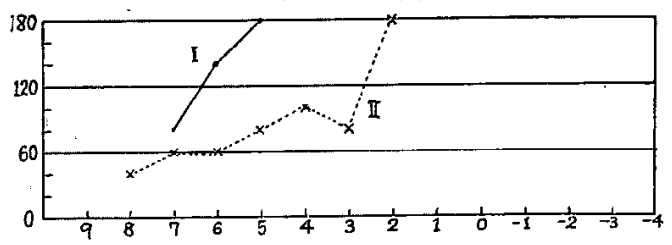

第 15 図

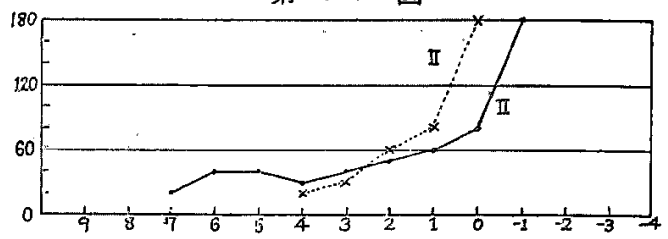

第 16 图

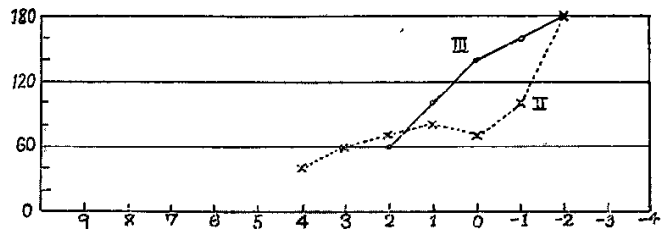

第 23 表

\begin{tabular}{|c|c|c|c|c|c|}
\hline 左 & $I$ & $\mathbb{Z}$ & III & $\mathbb{N}$ & |zेt \\
\hline$I$ & 3 & $z$ & $I$ & 0 & 6 \\
\hline$\overline{I I I}$ & 2 & $\overline{6}$ & 3 & 0 & $H$ \\
\hline III & 0 & 4 & 3 & 0 & 7 \\
\hline IV & 0 & 1 & 0 & 3 & 4 \\
\hline \begin{tabular}{c|c|}
+1 \\
\end{tabular} & 5 & 13 & $?$ & 3 & 188 \\
\hline
\end{tabular}

例が、型であつた，異型の ものは13 例で I 型と【 型が 4 例，I型之田型加 1 例, II 型と形型 7 例, I 型と N型が 1 例であつた.

4）毀疾患とグラフ型と の関倸：総数 28 例中, 慢

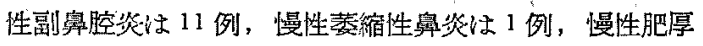

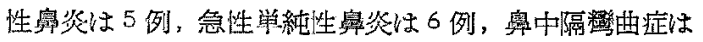
5 例であつた。グラフ型と疾患との関係は第 24 表に示 す通りで左右同型! 15 例中 I 型は総て急性単純性鼻炎之

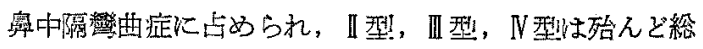
て慢性副鼻腔炎，慢性肥厚性鼻炎，慢性菱縮性舅炎に上

第 24 表

\begin{tabular}{|c|c|c|c|c|c|c|}
\hline & 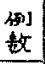 & & 5 周 & 型( & & 䖽型 (13利) \\
\hline 慢性副楀堙炎 & 11 & 0 & 4 & 2 & 1 & 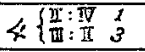 \\
\hline 萎繶性算炎 & $t$ & 0 & 0 & 0 & 1 & 0 \\
\hline 肥厚性臬炎 & 5 & 0 & 1 & 1 & 1 & $2\{$ II:II 2 \\
\hline 急性鼻炎 & 6 & 2 & 1 & 0 & 0 & 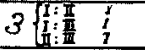 \\
\hline 鼻中隔弯曲症 & 5 & 1 & 0 & 0 & 0 & $4\left\{\begin{array}{lll}1: \text { II II } & 3 \\
1\end{array}\right.$ \\
\hline 言十 & 28 & 3 & 6 & 3 & 3 & 13 \\
\hline
\end{tabular}


つて占められた。型であつた 13 例中，片側が I 型で あつたものは 5 例でこれ等は総て急性単純性奥炎子率的 隔彎曲症で，その中 4 例は一側が』型であつた．

\section{第 4章 考：按}

唤営疲労の起源に就ては従来，あるいは束松にあるい は中枢にその位置求められている．即ら Elsberg が 一側鼻の疲労は他側の刺激閾値を上昇せしめる事を証明 したのに対して，Jacques Le Magnen むこの焉を認 め,これは普通考克られるように疲学が単に末梢器官だ けに基ずくあのでないと云う事を㜔えさせると述べてい る. しかし乍ら一方，飯田は嗅細胞説を唱え，百合野む

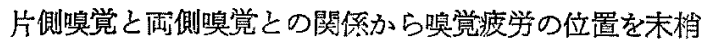
にあると推論した。喚覚疲労の位置がどの部位にあるか を知る事は，嗅党の本態究明に意義梁い事は勿論である

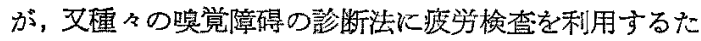
めの夜究にも役立つものである. 私恃穴右別唤党疫労に 関する实験を行つて特に疲労の位题に就ての考察を加兑 たので順に以下述べる事とする。

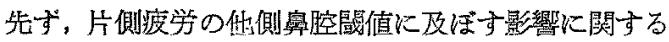

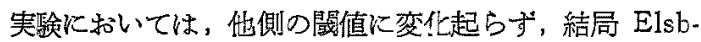
erg 等の成積之異り, 飯田, 百合野等の垁告之一致し た。次に連䋉刺激增加法による実煥の中，正常者圭右別

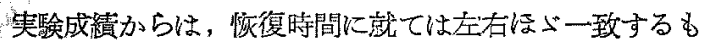
のが多く，更に疲学ク゚シフ型で部分の例で右同型 となつた。しかし少数乍ら空右異型のものがあつた事夷 は看避できない重要な点で市る，重疾患々者左右別実歌

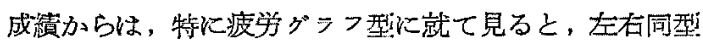
のものに刘し左右烡型のるのが幾分少い程度で, 型の組

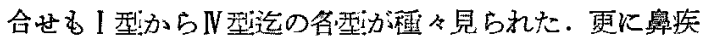
患とグシフ型との関係も，谷疾患に蛙いて左右異型が認 められた。

以上の諸点及び第 2 緛で得た知見を基礶として唤覚痕 労の発現する部位を考察す而之，嗅覚器官を自腔内に存 在する部分即ち嗅細胞の存する嗅粘䐉部之穊板を境界之 した頭盖内に存在する部分とに大きく分けて，前者を末 梢，後者を中枢と略称した場合，私は末梢を疲労発現の 位置々㘼光，百合野，飯田等の説に顀意を表するもので ある，何となれば，(1) 片側疫労が他側影響を及ぼさ ない事は，左右間に全く交涉の無い末梢において㕸めて 理解できる聚であり，(2) 連繶刺激增加法で正常者に扣 いても左右の噯覚疲学に型の相違が見られた事は，矢張

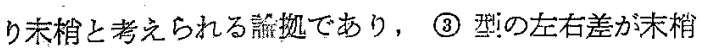

の位置する悬腔内の疾患に際して，正常者の場合よりる 缡かに高率汇琵れた事は (1) 正常者群よりも自疾患々者 群て病的疲労型が高率且つ高度に現れ，乙かも疾患の程 類に応じて型の比率が異つた聚，と共に疲労の位置を未 梢と教えねばならない理由となるからである，若し未梢 でなく中枢にあると仮定吉れぱ，(1)では多少とる他側 の䦪值上昇が起らねばならず，(2)では勿熘左右間に疲 学の度合を表現する型の根違が起る箱が無く，(3)，(4)

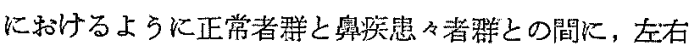
差の出現率は勿論, 疾㭧 (鼻副鼻腔病変)、火上る疲学型 の比率も，疾惠の有無に上る疲学型の差も生じない箱で ある・斯様にして，私は嗅覚疲学の位置を末梢即ち犑細 胞に諰定したのであるが，噂覚以外の感覚特に聴覚では

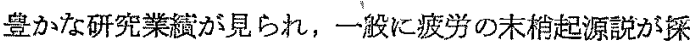
用されている琴状で，特に毛絴胞を重要視している人る

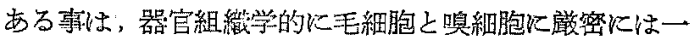

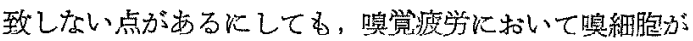
重要な役割を演ずる哥恃充分淮察し得るもの上思わ㧈 る.

\section{第与章 結論}

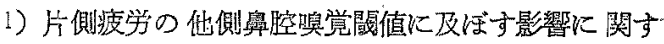
る笑験を正常者 10 名に就て行つたが，影隦は認められ なからた。

2）通続刺激增加法汇より，正常者 16 名の 32 側，楀

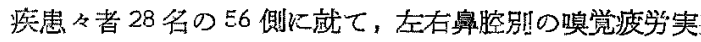
駼学行つた。

3）特に疲労グンフ型に関しては, 正常者では16 例中 3 例が 左右異型であつたのに対し，鼻疾患々者では 28 例中 13 例が左右異型であり，包各鼻疾患夫々に和いて 慧型が認められた，

4）本成続から哭覚疲労の位置を末稍と推差した。

\section{文献}

1) Aronsohn: Experimentelle Untersuch. Z. Physiol. d. Geruchs., Du Bois Arch. S. 53, 1886.2 2) Elsberg: Medical Physics, Chicago Year Book. Publishess, 1944. 3) Hermanides: Über die Konstanten der in der Olfaktologie gebräuchlichen neven. Standardgerüche. Inaug. Diss, 1509. 4) Jacques Le Magnen: Odeurs et Parfums. 5) Woodrow G Karpmann: J. exp. Psychol. 2, 1917. 6) Zr:aardemaker: Die Adaptation bzw. die Ermüdung. Denker-Kahler's Hdb. d. Hals usw. heilk. Bd. I, 
S. 469, 1925, 7) 浅井健吉: 嗅覚の心理学・疲労, 日耳鼻全書，4巻，1，52 頁 1933 . 8) 花岡利昌：嗅 覚, 現代生理学, (5), 78頁, 1958. 9) 針ヶ谷正孝:

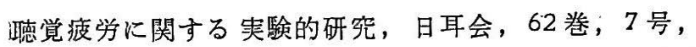
8450 頁, 1959. 10) 飯田正千代：嗅覚関する臨床 的研究, 福岡医誌, 10巻, 1号, 123面, 1916. 11) 市 原正雄, 他：嗅覚に関寸る研究第 1 報, 嗅覚計に就て, 日耳会, 61 卷, 11 号, 2018 頁, 1958.12 ) 市原正雄, 他：嗅覚に関する研究第 2 報, 病的者の嗅覚に就て, 日耳会, 62 巻, 3 号, 331 面, 1959 . 13) 市原正雄, 他：㖵覚に関寸る研究第 3 報, 血行性嗅覚に就て, 日 耳会, 62 巻, 5 号, 955 面, 1959. 14) 市原正雄, 他： 嗅敩に関する研究第 4 報, 压力の闇值上刺激に就て, 耳 梨, 31 巻， 7 号，515 頁，1959. 15）市原正雃，他： 嗅覚に関する吥究第 5 報, 嗅素の連続稀釈による嗅覚検 查の意義に就て, 耳科, 32 巻, 2 号, 125 面, 1960.

6) 市原正雄, 他: 嗅覚に関する研究第 6 報, 特種瞕
業者の嗅覚汒就て、耳科, 32 巻, 3 号, 227 面, 1960. 17) 市原正雄, 他：嗅覚に関する研究第 7 報, 所謂嗅 覚脱失者の治療に就て, 耳科, 32 巻, 3号, 231 面, 1960. 18) 中村賢二：聴覚疲労に関与る研究，日耳 会, 59 巻, 11 号, 1920 頁, 1956. 19) 大和田健次郎： 連続音による閾值上年の臨床的観察, 日耳会, 61 巻, 2 号, 273 頁，1958.20）百合野寅松：嗅覚疲学検查 に関する一方法, 大日耳会, 30 巻, 1号, 150 面, 1923 .

終稿に当り恩師山本教授の御指導並びに御校 閲に深謝すると共に終始御教導を戴いた市原助 教授に感謝の意を表する。

本諭文の要旨は日本耳鼻咽喉科学会第363回 関東地方会例会において演述した。

（原稿到着 $=$ 昭和 35.3 .29 日一急載）
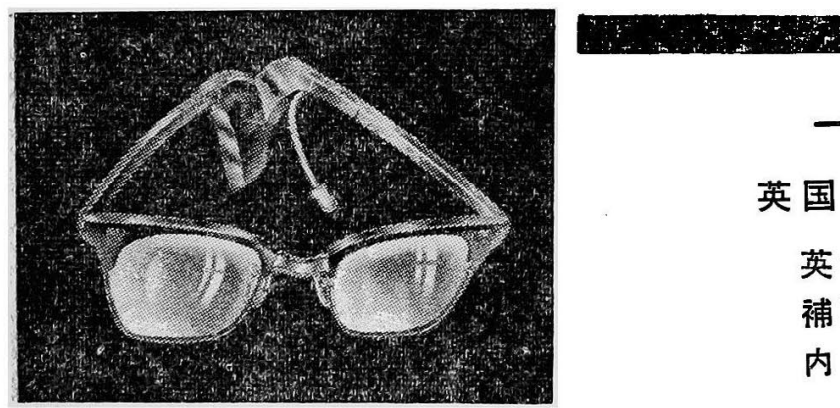

営業品目

英国製めが補聴器在庫脰富

英・米・独製各種新型補鲶器 補聴器用米国製水銀電池各種 内外補㯖 器修理改造

\section{補聴器の御用はどうぞ日本補聴器へ}

補聴器輪入販売專用の店

カタログ贈呈

\section{日本補聴器販売株式会社}

東京都千代田区神田駿何台三八十一

電話 (291) 0080 振替 東京 77872 